\title{
A 40 años del Concilio Vaticano II
}

\section{Proceso conciliar}

Don Demetrio Valentini, Obispo de Jales, Brasil.

La Iglesia se está preparando para celebrar los cuarenta años de la clausura del Concilio Vaticano II. Para esto está previsto un "sínodo", que se realizará en octubre del próximo año.

Los "ś́nodos" nacieron en el contexto del concilio y fueron pensados por Pablo VI como una especie de "miniconcilios" periódicos, que sostuvieran sus conclusiones y garantizasen la continuidad de su dinámica y de su espíritu.

Por lo tanto, en la intención de Pablo VI los sínodos debían significar que la Iglesia continuaba "en estado de concilio".

Pasados cuarenta años, la pregunta central a hacerse debería ser ésta: ¿continuó el concilio, o se estancó su dinámica? En particular, los "sínodos" ¿servirían para profundizar en los temas del concilio y para fortajecer el clima de participación y de renovación eclesial, o servirían de instrumento para amortiguar el impulso conciliar?

Por ahi percibimos que las intenciones de celebración de los cuarenta años del concilio no se limitan al estudio de un tema particular, como el de la eucarist́a, por más central que sea. Se trata de ver qué se ha hecho del concilio y retornar su espíritu, sus intenciones, sus desaffos, en las nuevas circunstancias de hoy.

En esta perspectiva, la propuesta de retomar el proceso conciliar, se presenta válida y pertinente. Ella puede comportar, en principio, la realización de una nueva asamblea conciliar. Pero, por el momento, señala la conveniencia de reconstruir el clima que resultó del anuncio del concilio, hecho por Juan XXIII, al inicio de su pontificado y que desató el Vaticano II.

Incluso antes de identificar posibles temas que fueran llevados a las deliberaciones conciliares, es preciso recuperar la "conciliariedad" de la Iglesia, 
reencontrar el espíritu conciliar. rehacer el ambiente de esperanza y de confianza que marcó los tiempos de la preparación y de la realización del Vaticano II.

Algunos aspectos de este clima sobresalen con evidencia.

Juan XXIII hablaba con mucha frecuencia de los "signos de los tiempos", que interpelaban a la Iglesia y a la humanidad y que esperaban respuestas adecuadas. Esto es suficiente para decir que son hoy tantas estas señales que nos dejan perplejos y nos invitan a un clima de escucha y discemimiento, en la actitud de quien quiere contar con la gracia de Dios.

Un proceso conciliar resalta la importancia de que estemos disponibles a la acción del Espŕitu. Tan permanente es la dimensión conciliar de la Iglesia, cuanto precisa ella de la permanente acción del Espíritu.

Esta apertura al Espíritu va en sentido opuesto al poder humano, que busca sus objetivos por la fuerza. Un verdadero clima conciliar diluye las disputas de poder, e invita a una amplia participación de todos, en la confianza de que encontremos juntos los caminos a seguir.

La celebración de los cuarenta años del concilio nos invita, en verdad, a reencontrar su Esplritu y a retomar su dinámica. Necesitamos un nuevo proceso conciliar.

21 de noviembre de 2004.

\section{Un mundo en proceso conciliar}

\section{Marcelo Barros, monje benedictino, Brasil.}

En estos días se cumplen cuarenta años del 21 de noviembre de 1964, cuando todos los obispos católicos del mundo -reunidos con el papa Pablo VI, en el Concilio Vaticano II- publicaron dos documentos, de gran repercusión en la marcha renovadora de las iglesias cristianas del mundo. El primero, la Constitución Lumen Gentium (Luz de los pueblos), propone un nuevo modo de ser Iglesia y de organizarse (como Iglesia). Contrario a verse, como en otros tiempos, como una organización internacional poderosa, temida por los hombres, la Iglesia se declara como parte del pueblo de Dios, que forma comunidades fraternas de discípulos y discípulas de Jesús de Nazaret, para curar al mundo de tantas heridas. Estas comunidades deben tener autonomía disciplinar y fisonomía local propias. Deben de ser diversificadas, de acuerdo con la cultura, en la cual se insertan. Así, testimoniarán la presencia del Espiritu de Dios. San Pablo escribió "Donde esté el Espíritu de Dios, allí hay libertad" (2Cor 3, 17). 
En la época del concilio, un autor laico escribió: "La Iglesia está llamada a ser una muestra de cómo debe ser el futuro de la humanidad. Ella es ensayo de la nueva sociedad que la mayoria de los seres humanos quiere vivir. Las personas deberian poder mirar a la Iglesia, ver cómo se viven en ella las relaciones humanas y decir: queremos que toda la sociedad sea asr". En el Concilio Vaticano II, la Iglesia caminó en este rumbo.

El segundo documento supera siglos de aislamiento y división que imperó entre las Iglesias cristianas. El Decreto Unitatis Redintegratio (Reintegración de la unidad) deja claro que la actual división entre las iglesias es contraria al evangelio: un obstáculo para que se realice la misión de dar testimonio del amor de Dios por toda la humanidad. Así, la Iglesia católica se integró en un movimiento ecuménico, que hacía más de cincuenta años habŕa sido fundado por misioneros evangélicos. De esta forma, la Iglesia católica desanolló las bases para el diálogo con otras culturas y religiones, superando siglos de cerrazón e intolerancia.

A partir de estos textos, los obispos redefinieron la misión de La Iglesia en el mundo: unirse a toda la humanidad, en la búsqueda y en el perfeccionamiento de todo lo que pudiera volver el mundo más justo y más fraterno. La fe no puede oponerse a la ciencia. Al contrario, debe unirse a toda investigación que sirva a la vida, a la paz y al justo progreso de la humanidad. A partir del concilio, las iglesias cristianas se convencieron de que ninguna guerra es justa y ninguna paz puede ser alcanzada, cuando dos tercios de la humanidad continúan sufriendo condiciones infrahumanas de supervivencia.

El Concilio Vaticano Il definió nuevas relaciones de fraternidad con el judarsmo y una actitud positiva de respeto y diálogo con todas las religiones y culturas. Dejó claro que la libertad religiosa es un derecho de todo ser humano. O sea, cualquier ser humano puede no adherirse, incluso, a ninguna religión, sin disminuir en nada su carácter sagrado de imagen divina en el universo.

El bueno y santo papa Juan XXIII quiso que aquel concilio representase para la Iglesia lo que una nueva primavera es para el mundo. De hecho, desencadenó un proceso de cambios, que, a pesar de muchos obstáculos y tensiones, es irreversible. En estos cuarenta años, gran parte de los pastores y de los fieles de la Iglesia católica intentaron dar marcha atrás o detener este camino, por el cual el Espíritu nos empuja, pero nadie consigue rehacer el pasado. Las personas que buscan la verdad y se dejan tocar por el Espíritu saben que una Iglesia que hace lobby para imponer a toda la sociedad sus propios valores es tan cristiana como escribir el nombre de Dios en billetes de dólar, o como los poderosos del gobiemo norteamericano que, en este jueves, matarán un pavo y celebrarán el Día de acción de gracias. Dios se siente mucho más perjudicado por este tipo de alabanza y de servicio, que el pavo, muerto para la cena de la fiesta. 
En el mundo entero, grupos cristianos festejan los cuarenta años de los documentos del concilio. Muchos piden a Dios que conduzca de nuevo a las iglesias al diálogo amoroso con la humanidad, a una renovación interior, que restituya, a fieles y a pastores, la libertad del Espíritu. Que toda Iglesia cristiana pueda ser para la sociedad un laboratorio de paz, de compromiso con la justicia y de cuidado de la naturaleza.

22 de noviembre de 2004. 